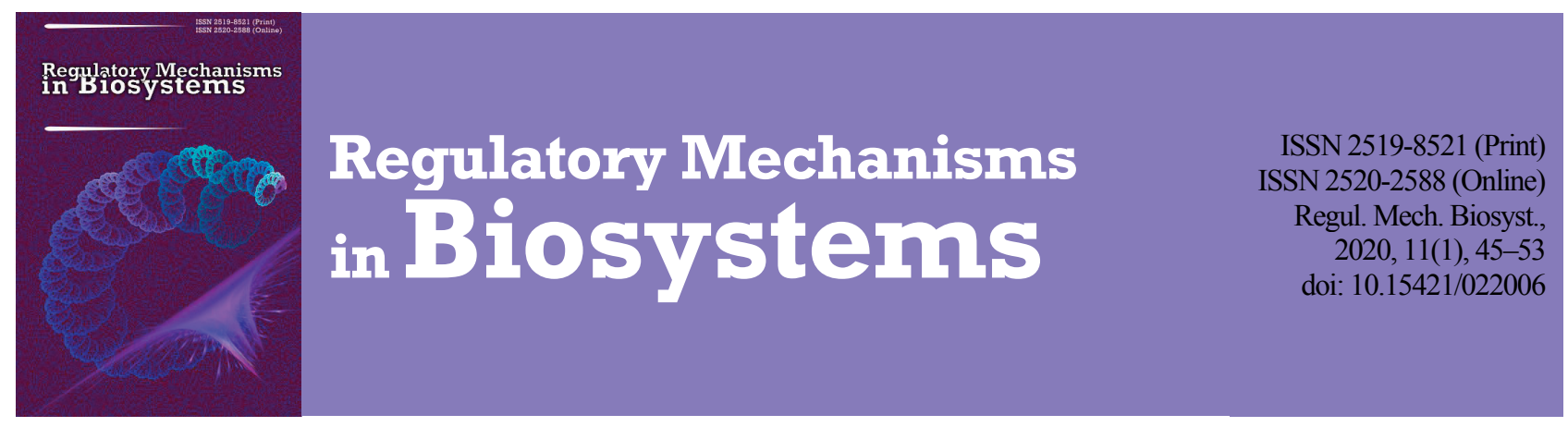

\title{
Characteristics of immunity to leaf diseases of winter wheat samples under the conditions of the north-east forest steppe of Ukraine
}

\author{
O. M. Osmachko, V. A. Vlasenko, O. M. Bakumenko, V. I. Bilokopytov \\ Sumy National Agrarian University, Sumy, Ukraine
}

Article info

Received 27.12.2019

Received in revised form 20.01.2020

Accepted 22.01.2020

Sumy National

Agrarian University,

G. Kondratyiva st., 160

Sumy, 40000, Ukraine.

Tel.: +38-066-362-69-72.

E-mail:

lenaosmachko1978@ukr.net

\author{
Osmachko, O. M., Vlasenko, V. A., Bakumenko, O. M., \& Bilokopytov, V. I. (2020). Characteristics of immunity to leaf diseases \\ of winter wheat samples under the conditions of the north-east forest steppe of Ukraine. Regulatory Mechanisms in Biosystems, \\ 11(1), 45-53. doi:10.15421/022006
}

To realize the genetic potential of the productivity of bread winter wheat varieties, it is necessary to maintain a certain level of plant resistance to disease. Resistance donors may lose this property as a result of changes in the virulence of the pathogen and defeat of the genetic systems of plant resistance. This makes it necessary to search for new resistance sources and donors to leaf diseases. Our researches were conducted using field, laboratory and mathematical-statistical methods. Phenological observations, accounting, evaluation and harvesting were conducted according to currently accepted methods. 86 bread winter wheat samples from the 4th WWSRRN CIMMYT were studied for resistance to leaf diseases in our research during 2014-2016. The manifestation of variability depended significantly on the genotype for three diseases. The highest genotype influence was obseved in resistance to septoria disease, where it was $81 \%$. On average the highest indicator of resistance (7.7) to powdery mildew during the three years of research was observed in the mid-late ripening samples. The mid-early ripening group was considered to be the most adapted to the powdery mildew pathogen in the Northeastern Forest-Steppe. The highest average indicator of resistance (7.5) to brown rust for the three years of research was found in the early ripening group. The samples of the mid-ripening group were most adapted to the brown rust pathogen. The highest average resistance to septoria disease was also found in the early ripening group. The best adaptation to septoria disease was observed in mid-late ripening samples. $36 \%$ of the samples were resistant to three diseases. As a result of the research, a number of CIMMYT samples were isolated from the 4th WWSRRN, which exceeded the standard in resistance to powdery mildew, brown rust and septoria disease. They were characterized by better performance. Valuable forms for breeding work that can be resistance donors to leaf diseases were identified among them.

Keywords: resistance; powdery mildew; brown rus; septoria disease; pathogen; yield capacity.

\section{Introduction}

Global climatic changes have a negative impact on global trends in crop production, which undoubtedly affects our country. Every year winter wheat crops are affected by extremely low or high temperatures and they suffer from disease and pests. A significant proportion of domestic and foreign wheat breeding varieties have not been adapted to the new global climate warming and drought, which have recently been observed during the vegetation period in the natural and climatic zones of Ukraine As a result, wheat yield capacity is unstable and individual farms suffer from significant economic losses (Morgun et al., 2014). The problem of crop protection against disease does not lose its relevance in modern grain production. The need of the world market for environmentally friendly agricultural products leads to the tendency to reduce the use of chemical plant protection products against pathogens (Brygadyrenko \& Nazimov, 2015; Reshetniak et al., 2017). An alternative to pesticide use is the cultivation of resistant varieties. They reduce the usage of pesticides which are hazardous to humans, animals and the environment (Mukha \& Zayima, 2013).

Modern world and advanced domestic developments in genetics and breeding, connected with creation of new plant varieties, are characterized by wide application of both classic methods and the latest molecular and genetic developments in this branch (Kovalyshyna et al., 2017). Vlasenko et al. (2012) conducted an analysis of the genealogy of wheat varieties, which determined a very high level of successful application of the distant hybridization method by scientists in many countries (the USA, England,
Sweden, Germany, Italy, France, etc.). The results prove the great effectiveness of this method, and it allows radical changes to be made in the heredity of important economic features of the plant organism and the creation of new valuable forms and plant varieties that provide the expansion of genetic wheat diversity. The combination of varied innovative genetic and molecular technologies with traditional breeding allows us to obtain new high-yielding, high-tech varieties of crops adapted to modern climatic challenges (Morgun et al., 2014).

Yachevska (1990) made a thorough review of foreign studies of using the distant hybridization method in wheat breeding.

The main conclusion is that many species and genera related to bread wheat are the carriers of inexhaustible genetic properties. They are introduced by many breeders of the world into the wheat genome, increasing its resistance against various diseases, pests and stressful environmental conditions. So they increase the yield capacity, the grain quality and achieve their higher stability.

Worldwide, powdery mildew caused by the fungus Blumeria graminis f. sp. tritici is a major wheat disease. The pathogen can cause significant crop losses in epiphytotics. The use of genetic resistance is the most effective approach to control the disease. To identify the genomic regions responsible for the US winter wheat resistance and to identify DNA markers in these regions, Na Liu et al. (2017) conducted studies on the associated genomic set of 185 winter wheat samples. They identified markers associated with the nine quantitative loci characteristic and simple sequence markers (SSR) associated with three loci responsible for powdery mil- 
dew resistance. Most of the loci in the US winter wheat population have been reported before, but loci on 1A, 6A, and 1B chromosomes are probably new. Germplasm with immunity to powdery mildew is a good resistance source and it can be used in further breeding work.

The N0324 wheat line obtained from Triticum dicoccoides Thell as a result of 5055/Shaan 253 crossing provides effective protection against powdery mildew. The analysis of 205 samples in F2 created by crossing N0324 with the susceptible variety Shahany 225 determined that in Russia resistance of N0324 line was controlled by a single recessive gene, temporarily identified as Pm5055. Four SSR markers, such as Xwmc441, Xbarc7, Xbarc13, and Xbarc55, were connected with the gene at a distance of 10.6, 23, 23, and 23.9 microns, respectively. Chinese Spring nulli-tetrasomic and ditelosomic lines were used to determine chromosomal marker locations. The results showed that this gene can be located on chromosome 2B. Pm5055 can be used to diversify sources of resistance to powdery mildew in future breeding programs for wheat varieties (Mamoudou et al., 2016).

The creation of wheat lines with alien translocations facilitated the practical use of distant species in wheat improvement. The Robertson translocation of Triticum aestivum / Thinopyrum bessarabicum in 6D wheat chromosome from $6 \mathrm{~Eb}$ Thinopyrum bessarabicum $(2 \mathrm{n}=2 \mathrm{x}=$ $14, \mathrm{EbEb})$ occurred through a chromosomal rearrangement - fusion. The F2 population was obtained from the plant crossing between the $\mathrm{DS6Eb}(6 \mathrm{D})$ line and the Roushan bread wheat variety $(2 \mathrm{n}=6 \mathrm{x}=42$, AABBDD). Three PCR-based markers that were characteristic for chromosomes $6 \mathrm{D}$ and $6 \mathrm{~Eb}$ were used for screening F2 plants. A homozygous line with complete fertility was detected among F3 families and tested by genomic line in situ hybridization (Ardalani et al., 2016).

In wheat breeding programs the accurate and rapid detection of 6RL chromatin in the wheat genotype is essential for the effective use of elite genes on the long arm of 6 (6RL arm) rye chromosome. PCR-specific $6 R L$ markers can foster the detection of elite 6RL genes in wheat breeding. A limited number of 6RL-specific markers were developed. 300 of new PCR-specific 6RL-specific markers were detected in the research. SLAF-seq fragment sequencing technology was used. The fragments were additionally physically mapped in four areas on 6RL arms using $6 \mathrm{R}$ and 6RL lines. In addition, 95 of 300 markers demonstrate polymorphisms that can be used to investigate the diversification of the 6RL rye genome. The markers developed in this research can be used to identify predetermined 6RL segments in the wheat background mode and to accelerate the use of elite 6RL genes in wheat breeding (Li et al., 2016).

Allelic resistance genes of Pm3 to wheat give specific resistance to powdery mildew (Blumeria graminis $\mathrm{f}$. sp. tritici Bgt) and encode nucleotide-binding domains rich in leucine-rich repeated (NLR) receptors (Koller et al., 2018). Transgenic wheat lines overexpressing alleles Pm3a, $\mathrm{b}, \mathrm{c}, \mathrm{d}, \mathrm{f}$, and $\mathrm{g}$ were previously formed by transformation of the Bobwhite variety and tested in field studies. They showed various degrees of resistance to transgene-controlled powdery mildew. Scientists from China tested four transgenic lines, each of them had two pyramidal Pm3 alleles, which were formed by crossing line transformed by single Pm3 alleles. All four allele-pyramid lines showed improved resistance to powdery mildew in field studies compared to their parent lines. The increased resistance results from two effects of increased expression levels of the common transgene and allele-specificity combinations. The plant development and the yield capacity indicators of the pyramid lines did not cause any negative effects. On the contrary, in the Pm $3 b \times P m 3 f$ pyramid line, the normal plan development was restored compared with the developmental delay and the seed set of the Pm3f parent line decreased. The allele-specific RT qPCR marcers showed additive levels of two Pm3 alleles transgene expression in the pyramid lines. There is a positive correlation between the expression level of the common transgene and resistance to powdery mildew. In summary, the pyramidal alleles of the Pm3 transgene are successful in increasing resistance to powdery mildew.

17 pathogenic populations were studied in China (Sichuan province). 109 isolates were classified into two separate groups (Liu et al., 2015). 92 isolates had a high virulence and 17 isolates had low virulence. The populations from Ibin (Southern Region), Sichan (Western Region) and Meishan (Middle Region) showed lower virulence rates than popu- lations in other regions. Many of the previously known resistance genes did not provide resistance in this research. The Pm21 resistance gene showed an immune response to a pathogenic problem with all Sichuan populations, and Pm13, Pm5b, Pm2 + 6, and PmXBD maintained tresistance. High levels of gene flow were identified among the populations of four regions. Closely related populations in each region differed by cluster analysis with ISSR and SRAP alleles. ISSR and SRAP allele profiling analysis revealed a high level of genetic diversity among pathogenic populations in Sichuan province. Although the analysis of the ISSR and SRAP profiles showed similar effects, the SRAP allele appeared to be more informative. The researchers didn't find significant association between these alleles and virulence or the pathogen pathogenicity. The results showed that the ISSR and SRAP alleles are more effective for characterizing small or limited populations.

To identify new genes for powdery mildew resistance from Dasypyrum villosum, a relative of wild wheat, scientists evaluated the Chinese Spring-D varieties (Zhang et al., 2016). Based on the evaluation data, they concluded that the chromosome $5 \mathrm{~V}$ D. villosum controls resistance to the powdery mildew pathogen. Plants of the T5VS homozygous line from 5AL translocation (NAU421) were with absolute fertility. They are further characterized using sequential genomic hybridization in situ, C-band, and EST-STS marker analysis. The dominant gene Pm55 was located in the chromosome buffer 5VS 0.60-0.80. 5B introgression was evaluated in seedlings and adult stages of plant development. This study demonstrated that Pm55 provides a new type of powdery mildew resistance. The T5VS/5AL translocation line gives an opportunity to broaden the spectrum of grain texture to a super-bread category. Accordingly, this gene is a new source of resistance to powdery mildew and may be useful both in the study of the resistance mechanisms of and in the improvement of bread wheat.

Hao (2018) detected the Pm56 mildew resistance gene in 6A wheat chromosome, which was transferred from rye chromosome $6 \mathrm{R}$ in the form of spontaneous balanced translocation. The differential disease response of plants harbouring various fragments of $6 \mathrm{R}$ indicated that a powdery mildew resistance gene(s) was present on both arms of rye chromosome 6R. Based on karyotyping, the short arm gene, designated Pm56, was mapped to the subtelomere region of the arm. The Robertsonian translocation 6AL/6RS can be exploited by wheat breeders as a novel resistance resource.

Pm57 a new resistant gene against powdery mildew, was transferred into common wheat from Ae. searsi and further mapped to $2 \mathrm{~S} \mathrm{~s}$ \#1L at an interval of FL0.75 to FL0.87. The wheat chromosomes involved in five of these recombinants were identified by FISH and SSR marker analysis and three of them were resistant to powdery mildew. The PCR marker X2L4g9p4/HaeIII was validated to specifically identify the Ae. searsii 2 Ss\#1L segment harbouring Pm57 in T2BS.2BL2Ss\#1L against 16 wheat varieties and advanced breeding lines, and the development of more user-friendly KASP markers is underway (Liu et al., 2017).

Aegilops tauschii is an excellent source of disease resistance that is transferrable to $T$. aestivum. The source TA1662 $(2 \mathrm{n}=2 \mathrm{x}=\mathrm{DD})$ was crossed with the powdery mildew susceptible line KS05HW14 (2n = $6 \mathrm{x}=\mathrm{AABBDD}$ ) followed by backcrossing to develop a population of 96 BC2F4 introgression lines (Wiersma et al, 2017). Genotyping by sequencing was used to develop a genetic map of the entire genome that was linked to Ae. tauschii reference genome. Bgt analysis with peeling was used to select the introgression lines and it was found that the resistance was as a separate locus $(\chi=2.0, \mathrm{P}=0.157)$. The resistance $\mathrm{Pm} 58$ gene is mapped on the 2DS chromosome. Pm58 was evaluated under the field condition in replication experiments in 2015 and 2016. It was detected in one of the Pm58 loci that reduced the powdery mildew prevalence and explained $21 \%$ of changes in the field $(\mathrm{P}<0.01)$. KASPTM analyses were developed from closely related GBS-SNP markers, a genetic map was refined, and four markers identified by Pm58 were determined. This new source of resistance will help to originate wheat varieties resistant to powdery mildew.

The worldwide distribution of rye 1RS translocations contained in wheat varieties for commercial purposes is largely explained by the fact that they carry disease and pest resistance genes. The 1BL/1RS translo- 
cation contains Pm8 - the resistance gene to powdery mildew (pathogen - Blumeria graminis), Sr31 - the resistance gene to stem rust (pathogen - Puccinia graminis), Lr26 - the resistance gene to brown rust (pathogen Puccinia reccondita) and $\mathrm{Yr} 9$ - the resistance gene to yellow rust (pathogen - Puccinia striiformis) (McIntosh et al., 1998). The 1AL/1RS translocation of the Amigo variety carries the resistance gene to aphids $\mathrm{B}$ and $\mathrm{C} \mathrm{Gb} 2$, Aceria tosicheilla (Keifer) $\mathrm{Cm} 3$ mite, a powdery mildew resistance gene Pm17, a gene for resistance to stem rust SrA1R (McIntosh et al., 1998, 2005). Genes containing wheat-rye translocations under the Northeast Forest-Steppe conditions provide resistance to varieties. According to the productivity elements the translocation carriers are characterized by high combining ability, they form higher and more stable grain yields (Bakumenko \& Vlasenko, 2018).

Rye (Secale cereale L.) chromosome-specific markers can contribute to the effective utilization of elite genes of rye in wheat (Triticum aestivum L.) breeding programs. Qiu (2016) developed 578 new ryespecific markers using specific length amplified fragment sequencing (SLAF-seq) technology, and 76 markers displayed different polymorphism among Kustro, Imperial, and King II rye. A total of 427 and 387 markers were, respectively, located on individual chromosomes and chromosome arms of Kustro by using a set of wheat-rye monosomic addition lines and 13 monotelosomic addition lines, which were derived from $T$. aestivum L. 'Mianyang11' $\times S$. cereale L. 'Kustro'. In addition, two sets of wheat-rye disomic addition lines, which were derived from T. aestivum L. var. Chinese Spring $\times S$. cereale L. var. Imperial and T. aestivum L. 'Holdfast' $\times S$. cereale L. var. King II, were used to test the chromosomal specificity of the 427 markers. The chromosomal locations of 281 markers were consecutive among the three sets of wheat-rye addition lines. The markers developed in this study can be used to identify a given segment of rye chromosomes in wheat background and accelerate the utilization of elite genes on rye chromosomes in wheat breeding programs.

The genomic sequence based on the Chinese Spring wheat chromosomal scheme allows development of large-scale markers of polymerase chain reaction (PCR) specific to homoeologues (Zeng et al., 2016). Based on the Chinese Spring genes, Zeng et al. (2016) developed 183 homoeologous-specific markers for 4B and 7B chromosomes. These markers were used in PCR tests for nullisomes $4 \mathrm{~B}$ and $7 \mathrm{~B}$ and their line of euploid synthetic hexaploid wheat (SHW) generated from hybridization between Triticum turgidum (AABB) and wild diploid species Aegilops tauschii (DD). These studies confirmed that up to $64 \%$ of markers for chromosomes 4B or 7B against the SHW background are homoeologous-specific. Thus, these markers had a very good ability to to be transfered between bread Chinese Spring wheat and SHW lines. Homoeologous-specific markers developed using genes with known functions may be useful for genetic studies, including home-based chromosome tracking and homoeological expression and interaction analysis.

Aegilops speltoides Robertson translocation includes all Ae. speltoides chromosomal arms, except the long arm of the homologous group of 4 chromosomes (Liu et al., 2016). Aegilops speltoides of the genus Poaceae is the most likely donor to the genomes of the B and G polyploid species of Triticum, as well as an important source of wheat resistance to diseases and pests. Most RobTs were fully fertile and they facilitated gene mapping and accelerated the introgression of agronomically useful traits into wheat by homologous recombination.

The agent of brown rust - Puccinia recondita f. $\mathrm{sp}$. tritici Rob. Et Desm. (syn. P. triticina Erikss.) is adapted to different climatic regions, so it is observed in all areas of the world in wheat cultivation. This is a specific disease of wheat, which causes large scale crop failure, especially in the Forest-Steppe and Polissya of Ukraine. Brown rust epiphytotes occurred 2-3 times every 5 years in Ukraine (Vozhzhova, 2018).

One of the priority directions for winter wheat breeding is to provide resistance to brown rust. Gene Lr34 provides wheat resistance by type of slow pace of development. The results of identification work in 646 samples of the gene Lr34 bread winter wheat and its allelic condition are presented. The alleles of the Lr34 gene were evaluated by the codominance of the molecular SNS marker csL V34 by the polymerase chain reaction method. 238 samples that carry the brown rust resistance gene Lr34 in the dominant allelic condition were identified (Kovalyshy- na \& Dmytrenko, 2017; Kovalyshyna, 2018). Scientists from the National University of Life and Environmental Sciences of Ukraine, the Institute of Plant Protection of the NAAS of Ukraine and the V. M. Remeslo Mironivka Institute of Wheat identified the allelic condition of the Lr34 gene among the 15 studied varieties (Kovalyshyna \& Dmytrenko 2017; Kovalyshyna, 2018). Only three cultivars - Berehynia Myronivska, Dniprianka MIP and Balada Myronivska - contain the Lr34 $(+)$ allele, which is only $20 \%$ of the studied varieties. The Lr34 gene is known to be non-specific. It provides overall resistance to various brown rust pathotypes in adult plants. Therefore, the results show that when creating new wheat varieties resistant to brown rust, it is necessary to use varieties with the identified "resistant" allele of the Lr34 gene, as the resistant source in breeding.

Kenya wheat Kenya Kongoni (Triticum aestivum L.) has a high level of plant resistance to leaf rust and yellow rust (Calvo-Salazar, 2015). Kenyan scientists identified genomic regions associated with rust resistance in a population of 148 recombinant inbred lines generated from crossing between Avocet-YrA and Kenya Kongoni. Field experiments to characterize the plant resistance to leaf rust and yellow rust were conducted in Mexican and Uruguayan environments. A connection map with technology of 438 different arrays and 16 simple sequence repetition markers was built using JoinMap 4.1. Genetic analyses showed that resistance to both diseases under study was determined by four to five genes, including Lr46/Yr29 and Sr2/Lr27/Yr30. Quantitative loci analyses of traits showed that pleiotropic loci of APR QYLr.cim-1BL, corresponding to Lr46/Yr29 and the predicted new QYLr.cim-7BL, are 5-57\% and $12-35 \%$ of the phenotypic variation for resistance. These loci, in combination with other three LR QTLs and two YR QTLs, respectively, provided high levels of resistance to both leaf rust and yellow rust in wheat in Mexican and Uruguayan environments. Other identified QTLs, QLr.cim-1DS, QLr.cim-2BL, and QYLr.icm-7BL may be new loci for both rust forms in common wheat (Calvo-Salazar, 2015).

Twenty-six wheat genotypes were evaluated for the level of plant resistance to leaf rust in two different locations (Shybin El-Kom and ItaEl-Barrow) during two consecutive growing seasons 2011-2013 (Fahmi et al., 2015). Wheat varieties Sids 12, Sids 13, Misr 1 and Misr 2, Shandweel 1, Beni Sweif 4 and Beni Sweif 5 have specific resistance. Meanwhile the genotypes of wheat with Lr 34 (Giza 165, Giza 168, Sakha 8, Sakha 94, Sakha 95, Gemmeiza 5, Gemmeiza 7, Gemmeiza 9, Gemmeiza 10, Gemmeiza 11) showed high level of resistance to brown rust. Other tested varieties were highly susceptible to this pathogen: Giza 160, Giza 163, Giza 164, Sakha 69, Sakha 93, Sids 1 and Giza 139. To confirm the presence of the Lr resistance gene of 34 adult plants, the SSR marker, ie the cslv34b allele was used in the tested genotypes (150 bp).

The Chkhetri (2016) study was planned to detect resistance to three rust diseases (leaf, stem and yellow) in new varieties under field conditions. The RIL population was evaluated for 2012-2013 and genotyped with DArTseq. The link map was constructed using 3439 DArTseq markers with an average density of $2.7 \mathrm{~cm}$. The composite display interval identified three QTLs for stem rust and leaf rust W195/BTSS RIL. Two consecutive QTLs for stem rust, QYr.sun-3BS and QYr.sun-4DL were introduced by W195 and one incompatible QTL, QYr.sun-7AS, BTSS, for leaf rust QLr.sun-2BS and QLr.sun-3BS was made by BTSS and QLr.sun-4DL using W195. It was demonstrated that QLr.sun-2BS Lr23.BTSS restrained the QTL stem rust; QSr.sun-2BL and QSr.sun6AS and QSr.sun-4DL were introduced by W195.QSr.sun-6AS, which corresponded to the Sr8a resistance gene, which is a BTSS carrier. Located QTL for all three rust diseases in 4D chromosome corresponded to the Lr67/Yr46/Sr55/Pm46 locus based on genotyping with the associated SNP marker. The interaction between QTL and rust virulence conditions was demonstrated. QYr.sun-3BS, QLr.sun-3BS and QSr.sun-2BL were presented by new disease resistance loci.

Shyshkin et al. (2018) researched the identification of resistance genes (Lr) to brown rust at the early and adult stages of winter wheat growing to obtain full immunological characteristics of newly originated varieties. 37 varieties of winter bread wheat were studied in infectious fields of the south and northwest of Russia, as well as with methods of 
phytopathological test (up to three isolates of the fungus with virulence to TcLr9, TcLr19, TcLr26) and with PCR analysis using 10 molecular markers Lr1, Lr3, Lr9, Lr10, Lr19, Lr20, Lr24, Lr26, Lr34 and Lr37. The research showed that among the studied varieties there were no universal ones resistant to all three clones. 11 varieties showed resistance to three clones, but in the germination phase they were affected by pathogens. In the researched varieties the resistance genes $\operatorname{Lr} 9, \operatorname{Lr} 19, \operatorname{Lr} 24$, Lr26 were also not detected with the PCR analysis. Of the 37 researched varieties, 29 contained Lr34 gene and 20 had an ineffective Lr3 gene that could not protect plants from brown rust in the field. It indicates that the resistant varieties carry additional unidentified $\mathrm{Lr}$ genes. Two resistance genes were determined in some varieties. The Kipchak cultivar had Lr1 gene, which lost its effectiveness. The difference between the degree of damage of some varieties under the conditions of Rostov region and St. Petersburg indicates the difference between the North Caucasian and northwestern populations in resistance to the pathogen of brown rust.

The most common and harmful pathogen of wheat stain is Septoria leaf Septoria tritici Rob. et Desm. (Suhomud, 2013). The harvest lost from septoriosis depends on the degree of disease development. Its share in the complex of the most common winter wheat diseases is from $7 \%$ to $25 \%$ in different regions of Ukraine. The disease is widespread in almost all wheat growing areas. Currently, several resistance genes to S. tritici were identified and named Stb. According to the data of scientists of the Plant Growing Institute (Kyrychenko et al., 2012), the first three genes - Stb1-Stb3 - are defined by Wilson (1985), Stb4 - Somasco (1990). Arraiano (2001) reported about Stb5 gene, a genetic source of its resistance was Ae. tauschii, and information of Brading et al., about the detection of Stb6. Genes with the constant symbols of Stb7Stb12 and StbAc1 and StbAc2 was also identified (McIntosh, 2008). Sources of the cultivated wheat resistance to the septoria disease pathogen are its related species (Triticale, Triticum timopheevii, T. fungicidum, T. monococcum, T. boeoticum, T. kiharae, T. urartu, T. zhukovskii, T. tauschii, etc.) and wild varieties (Agropyrun elongatum, Aegilops sguarrosa, Ae. speltoides, Ae. sharonensis), from which the resistance is transferred to cultivated varieties by interspecific and distant hybridization.

Winter wheat varieties originated and regionalized in Ukraine are generally not highly resistant to leaf diseases (Kyrychenko et al., 2012). Therefore, it is necessary to carry out deliberate work to originate varieties resistant to the studied diseases and to introduce them into breeding. It will reduce the infection and prevent the emergence of new pathogen races.

After literature source processing it became clear that the potential of foreign translocations to originate new varieties is not exhausted, since their manifestation is largely determined by the genotypic environment. So the searching for donors of leaf disease resistance among varieties and hybrids of domestic and foreign breeding, in particular among the samples of CIMMYT breeding-ground (International Center for Wheat and Corn Improvement), is relevant at this time. More than 140,000 unique wheat seed collections were collected at CIMMYT. According to its programs, this organization annually sends half a million packages of seeds to 600 partners in 100 countries. CIMMYT programs are aimed at improving the agricultural productivity in the countries of the world. The wheat specialist in the program, Nobel laureate Norman Borlaug worked with Mexican researchers and farmers to develop wheat genotypes that were disease resistant and showed much higher yield capacity than traditional varieties. New wheat lines are originated and selected under different climatic conditions (Khondoker et al., 2019).

From the world-renowned organization - International Center for Wheat and Corn Improvement (CIMMYT), we obtained the fourth winter wheat breeding ground resistant to stem rust (4th WWSRRN). They began to create this breeding-ground in early 2004-2005, when a race of stem rust Ug99 appeared. It affected about $90 \%$ of the world wheat assortment. For this reason, it was decided to create such a breeding-ground in CIMMYT (Khondoker et al., 2019).

As a rule, foreign translocations contain resistance genes to stem rust. The wide distribution of rye 1RS translocations in commercial wheat varieties is largely due to the fact that they carry disease and pest resistance genes. The $1 \mathrm{BL} / 1 \mathrm{RS}$ translocation contains $\operatorname{Pm} 8$ - powdery mildew resistance gene (pathogen - Blumeria graminis), $\mathrm{Sr} 31$ the resistance gene to stem rust (pathogen - Puccinia graminis), Lr26 - the re- sistance gene to brown rust (pathogen - Ycc9c) and the yellow rust resistance gene (pathogen Puccinia striiformis) (McIntosh et al., 1998). 1AL/1RS translocation from the Amigo variety carries the resistance gene to aphids $\mathrm{B}$ and $\mathrm{C} \mathrm{Gb} 2$, Aceria tosicheilla (Keifer) $\mathrm{Cm} 3$ mite, resistance to powdery mildew PM17, the resistance gene to stem rust SrA1R (Kozub et al., 2005; Khondoker et al., 2019).

Virtually to the end of the XX century, the rye resistance gene of Sr31 1LL/1RS translocation was effective against all known rusted stem races. The situation changed with the emergence of the Ug99 (TTKSK) race in Uganda, then in Kenya and with the threat of its further spread. The presence of rye 1BL/1RS translocation and $\mathrm{Sr} 31$ gene is not a reliable protection against stem rust, since TTKSK and related isolates are virulent to Sr31 (Pretorius, 2000). One of the genes that provide resistance to the TTKSK race of stem rust is the SrA1R gene, which is on the rye $1 \mathrm{AL} / 1 \mathrm{RS}$ translocation from Amigo. It is designated Sr1RSAmigo (Kozub et al., 2010; Olson et al., 2010; Bakumenko et al., 2015). It is this translocation that contains the resistance gene to powdery mildew PM17, which made it possible to hypothesize the resistance of the obtained samples simultaneously to two diseases of stem rust and powdery mildew. We decided to check the samples resistant to stem rust from CIMMYT breeding-ground for resistance to powdery mildew, brown rust and septoriosis disease, to select sources for further breeding work.

The aim of the study: to find out the immunological properties of the 4th WWSRRN CIMMYT samples for resistance to leaf diseases (powdery mildew, rust, septoria) in the northeastern forest-steppe of Ukraine and to identify the sources of resistance of the studied trait.

\section{Materials and methods}

The material was 86 CIMMYT samples from the 4th WWSRRN nursery (winter wheat stem rust resistant nursery). The laying out of research and phenological observations were conducted according to standard methods (Volkodav, 2003). The seeds of the collectable samples were sown with a manual seeder MS-1 in triplicate with a plot area of $1.2 \mathrm{~m}^{2}$. Plot placement was systematic. Sowing of the samples was carried out within the time limits allowed for the Northeastern ForestSteppe of Ukraine (from September 20 to October 2). Seed rate was at 5 million pieces/ha. The mineral fertilizers of Superagro $\mathrm{N}_{15} \mathrm{P}_{15} \mathrm{~K}_{15}$ with norm of $100 \mathrm{~kg} / \mathrm{ha}$ and early spring fertilization with ammonium nitrate $(100 \mathrm{~kg} / \mathrm{ha})$ were applied. The harvesting was done manually. The crop was converted to standard humidity.

The evaluation of the wheat resistance to leaf diseases was performed on a natural infectious background using varieties of infection carriers (Agassis - powdery mildew; Sel/Egin - brown rust; Borovii septoria disease). Resistance to powdery mildew and septoriosia disease was determined according to the modified Saari and Prescott scale from the tube exit phase to milky-wax maturity several times. The manifestation of resistance to brown rust was evaluated three times according to the 9-point integrated scale for cereal resistance assessment. The main consideration was the maximum disease manifestation, which was usually observed during the period of grain formation (Kyrychenko et al., 2012). Structural analysis of the bundle material was conducted to identify the yield properties of the varieties and the dependence of the yield elements on the pathogen damage was determined. The length of the stem, the mass of 1000 grains and the yield capacity were ascertained during the analysis. Biometric data processing was performed by mathematical and statistical methods (Dospehov, 1985).

The area under the research is characterized by a temperate continental climate with warm summers and not very cold winters with thaws. Weather conditions were analyzed according to the weather report of the Institute of Agriculture of the North-East of NAAS of Ukraine, which is located at a distance of $6 \mathrm{~km}$ from the experimental field. The highest rainfall over the years of research was in $2016-792 \mathrm{~mm}$ and the lowest rainfall was in $2014-553 \mathrm{~mm}$. The average annual air temperature over the years varied $+8.8 \ldots+9.5^{\circ} \mathrm{C}$. The highest sum of active temperatures was recorded during the growing season 2015/2016$3,489^{\circ} \mathrm{C}$, the lowest in $2014 / 2015-3,242^{\circ} \mathrm{C}$. In general, the contrasting weather conditions over the years of research promoted the compre- 
hensive evaluation of the studied samples. Therefore, the weather conditions of 2013-2016 were characterized as variable during the growing season. It means that CIMMYT samples were studied in different years for damage, which allowed us to study thoroughly the pathogenic complex and to evaluate the resistance of different genotypes.

Data analysis was performed using Statistica 5.0 program (FreeSoft, USA) was used to determine the significant factor contributions to assessing the adaptability of CIMMYT samples to disease resistance. Differences between maturity groups were determined using the Tukey test (with Bonferroni correction) with Statistica program 12.5.192.7 (StatSoft, USA). Where differences were considered reliable at $\mathrm{P}<$ 0.05 . The facts are presented in the tables in the form $\mathrm{x} \pm \mathrm{SD}(\mathrm{x} \pm$ standard deviation).

\section{Results}

We found a different norm of genotype response to hydrothermal conditions changes (Table 1) during the years of research (eco-gradient).

\section{Table 1}

Results of variance analysis for resistance to leaf diseases in samples of 4th WWSRRN CIMMYT bread winter wheat, 2013-2016

\begin{tabular}{|c|c|c|c|c|c|c|}
\hline \multirow{2}{*}{$\begin{array}{l}\text { The source } \\
\text { of variability }\end{array}$} & \multicolumn{2}{|c|}{ Powdery mildew } & \multicolumn{2}{|c|}{ Brown rust } & \multicolumn{2}{|c|}{ Septoria disease } \\
\hline & $\mathrm{F}$ & $\eta, \%$ & $\mathrm{~F}$ & $\eta, \%$ & $\mathrm{~F}$ & $\eta, \%$ \\
\hline Genotype & 67.7 & 65.4 & 721.6 & 41.3 & 48.1 & 81.3 \\
\hline Conditions of the year & 2.3 & 0.1 & 30.9 & 22.7 & 85.6 & 1.1 \\
\hline Interaction genotype + year & 14.9 & 28.7 & 40.4 & 27.9 & 6.3 & 11.9 \\
\hline Random & - & 5.8 & - & 8.1 & - & 5.7 \\
\hline General & - & 100.0 & - & 100.0 & - & 100.0 \\
\hline
\end{tabular}

Note: $\mathrm{F}$ - Fisher value; $\eta$ - the fraction of the factor influence.

The confidence level was less than $0.1 \%$ of significance on both factors for the three diseases. Therefore, different genotypes and conditions of the year have a statistically significant effect on resistance to powdery mildew, brown rust and septoria disease. Genotype was found to account for $65.4 \%$ of resistance powdery mildew in bread winter wheat , with $0.1 \%$ of resistance due to eco-gradient, $28.7 \%$ due to interaction of both factors, and about $5.8 \%$ due to random factors. As for the resistance to brown rust, the impact of the genotype was equal to $41.3 \%$, impact of the eco-gradient $-22.7 \%$, the interaction of both factors $-27.9 \%$, and random factors - about $8.1 \%$. As for the resistance to septoria disease, genotype impact was equal to $81.3 \%$ (the highest) the eco-gradient $-1.1 \%$ (the lowest), the interaction of both factors $11.9 \%$, and random factors - about $5.7 \%$. As a result, the variability manifestation of the analyzed trait according to all three diseases significantly depended on the the variety genotype and much less on the ecogradient and the interaction of these sources.

The first group includes early ripening varieties in which the average resistance reached the highest value (6.83) in 2014 (Table 2).

\section{Table 2}

Resistance to powdery mildew in samples of 4th WWSRRN CIMMYT bread winter wheat in maturity groups, 2014-2016 $(x \pm S D, n=4)$

\begin{tabular}{|c|c|c|c|c|c|c|}
\hline \multirow{2}{*}{$\begin{array}{l}\text { The group of } \\
\text { sample ripeness } \\
\text { (number of days } \\
\text { from spring awa- } \\
\text { kening to earing) }\end{array}$} & \multirow{2}{*}{$\begin{array}{l}\text { Amounts } \\
\text { of samples } \\
\text { in the group, } \\
\text { pcs. }\end{array}$} & \multicolumn{5}{|c|}{$\begin{array}{l}\text { Resistance to powdery mildew } \\
\text { ove the years, by points }\end{array}$} \\
\hline & & $\begin{array}{l}2014 \\
\text { points }\end{array}$ & $\begin{array}{l}2015, \\
\text { points }\end{array}$ & $\begin{array}{l}2016, \\
\text { points }\end{array}$ & $\mathrm{x} \pm \mathrm{SD}$ & $\begin{array}{l}\text { Min- } \\
\text { Max }\end{array}$ \\
\hline $\begin{array}{l}\text { Early ripening } \\
(58-60)\end{array}$ & 6 & $\begin{array}{l}6.83 \pm \\
0.26^{\mathrm{a}}\end{array}$ & $\begin{array}{r}4.17 \pm \\
0.17^{\mathrm{a}}\end{array}$ & $\begin{array}{l}4.52 \pm \\
0.03^{\mathrm{a}}\end{array}$ & $\begin{array}{c}5.17 \pm \\
0.15\end{array}$ & 6.83 \\
\hline $\begin{array}{l}\text { Mid-early ripenimg } \\
(61-63)\end{array}$ & 6 & $\begin{array}{c}6.53 \pm \\
0.24^{\mathrm{a}}\end{array}$ & $\begin{array}{l}7.81 \pm \\
0.14^{\mathrm{d}}\end{array}$ & $\begin{array}{l}7.86 \pm \\
0.14^{\mathrm{d}}\end{array}$ & $\begin{array}{c}7.40 \pm \\
0.17\end{array}$ & $\begin{array}{c}6.53- \\
7.86\end{array}$ \\
\hline $\begin{array}{l}\text { Mid ripening } \\
(64-66)\end{array}$ & 61 & $\begin{array}{l}7.10 \pm \\
0.06^{\mathrm{d}}\end{array}$ & $\begin{array}{l}7.13 \pm \\
0.09^{\mathrm{b}}\end{array}$ & $\begin{array}{r}6.89 \pm \\
0.02^{\mathrm{d}}\end{array}$ & $\begin{array}{c}7.04 \pm \\
0.06\end{array}$ & $\begin{array}{c}6.89 \\
7.13\end{array}$ \\
\hline $\begin{array}{l}\text { Mid-late ripening } \\
(67-70)\end{array}$ & 13 & $\begin{array}{l}7.20 \pm \\
0.13^{\mathrm{c}}\end{array}$ & $\begin{array}{l}7.89 \pm \\
0.04^{\mathrm{b}}\end{array}$ & $\begin{array}{l}8,00 \pm \\
0,26^{\mathrm{b}}\end{array}$ & $\begin{array}{c}7.70 \pm \\
0.14\end{array}$ & $\begin{array}{l}7.20- \\
8.00\end{array}$ \\
\hline
\end{tabular}

Note: different letters indicate values which reliably differed one from another within one column of the table according to the results of comparison using Tukey test with Bonferroni correction.

But the maximum score was only 9.0 (the cultivar Afina), the minimum score was 4.67 (the cultivar Seri). Over the years of research the lowest average indicator of resistance (4.17) to powdery mildew was in 2015, with a maximum of 9.0 (the cultivar Afina) and a minimum score 2.5. In 2016, the average resistance indicator was slightly higher (4.52), the maximum (9.0) - the cultivar Afina, the minimum (1.27). On average, over three years of research, the indicator of early maturing samples was 5.17. Compared to other groups, this score was the lowest with a variation of 2.66. The highest resistance rate was observed over three years in the cultivar Afina.

In the mid-early ripening group in 2014, the average resistance was at the lowest value (6.53), the maximum - 7.2 (samples Trakia// Maga74/MON/3/SHAHI/4/EBVD99-1), and the minimum - 5.0. In the 2015 growing season, the average resistance indicator reached 7.81, the maximum - 9.0, the minimum - 6.0. In 2016, the maximum score was 9.0. It was also fixed in MCCORMICK/Trego. Over three years of the research, the average indicator of the analyzed trait was 7.4 with a variation range of 1.33. MCCORMICK/Trego showed the highest resistance over the three years. RINA-6/4/BEZ/NAD//KZM(ES85.24)/3/F900K, TAM200/KAUZ/BEZ/NAD//KZM(ES85.24)/3/F900K, TAM 302/KS93U450 have higher resistance among the varieties of this group.

Mid-ripening morphotypes were included to the third group. In 2013/2014 the average resistance indicator of these varieties reached 7.1 points, the maximum $-8.8(\mathrm{Cv}$. rodinalAe. speltoides $(10 \mathrm{KR}))$, the minimum -4.7 . The average stability indicator in $2014 / 2015$ was the highest -7.13 , the maximum $-9.0(1744 / 7 \mathrm{C} / \mathrm{SU} / \mathrm{RDL} / 3 / \mathrm{CROW} / 4 /$ MILAN/5/ITOR, X84W063-9-18/U1324-25-1-4-4//K92/3/LE2301, and others), the minimum was 1.0 . In 2015/2016, the average stability indicator was 6.89, the maximum - 9.0 (RAN 96/GANSU-3, CMH72428/Morocco/3/BDFN/4/Temu36, and others), the minimum - 1.3. Over three years, the average stability score was 7.04 and the variation rate was 0.24 . Over three years among the varieties of this group Seri.1B*2/3/KAUZ*2/BOW//Kauz/4/Burbot-4/5/Boema, Rana96/GA NSU-3, OK81306/Mercan-2, Rina-6/4/BEZ/NAD//KZM(ES85.24)/3/ F900K, Cv. rodinalAe. speltoides (10 KR), Cv. Lada/K-62903, and others showed consistently higher resistance.

In 2014 in the group of mid-late varieties the average resistance to powdery mildew was the highest among all maturity groups - the score 7.2, but the lowest over the years of research, the maximum - 9.0 (Simano), the minimum - 5.3. The average resistance indicator in 2015 was also the highest among the previous groups - the score 7.89, the maximum -9.0 (EC-P, Fiorina, Simano), the minimum - 3.3. For the growing season 2015/2016, the average indicator was 8,0 and was the highest among the years of research, the maximum - 9.0 (T08/04, EC-P, SD92107-2/SD99 W042, Fiorina, Simano), the minimum - 3.2. Over three years of research, the average late samples had the highest stability score of 7.7 points among all groups, with a variation score 1.2. Among the varieties of this group over three years the following were characterized by high resistance - ID800994.W/VEE//Piopio/3/MNCH/4/FDL4/ Kauz, TAM-107/ T21, (KS95U522/TX95VA0011) F1/JAGGER, CH111.14422, Simano.

The average resistance of early ripening varieties in 2014 was the highest among the studied groups - the score 8.11 and the average over the years of research, maximum - 9.0 (Afina, HBF0290/X84W063-9392//ARH/3/LE 2301), minimum-4.10 (Table 3).

Table 3

Resistance to brown rust in samples of 4th WWSRRN CIMMYT bread winter wheat in ripeness groups, 2014-2016 $(x \pm S D, n=4)$

\begin{tabular}{|c|c|c|c|c|c|c|}
\hline \multirow{2}{*}{$\begin{array}{l}\text { The group of sample } \\
\text { ripeness (number of } \\
\text { days from spring } \\
\text { awakening to earing) }\end{array}$} & \multirow{2}{*}{$\begin{array}{l}\text { Amounts } \\
\text { of samples } \\
\text { in the } \\
\text { group, pcs. }\end{array}$} & \multicolumn{5}{|c|}{ Resistance to brown rust, by points } \\
\hline & & $\begin{array}{l}2014, \\
\text { points }\end{array}$ & $\begin{array}{l}2015, \\
\text { points }\end{array}$ & $\begin{array}{l}2016, \\
\text { points }\end{array}$ & $\mathrm{x} \pm$ & $\begin{array}{l}\text { Min- } \\
\text { Max }\end{array}$ \\
\hline $\begin{array}{l}\text { Early ripening } \\
(58-60)\end{array}$ & 6 & $\begin{array}{c}8.11 \pm \\
0.28^{\mathrm{a}}\end{array}$ & $\begin{array}{c}8.32 \pm \\
0.09^{\mathrm{a}}\end{array}$ & $\begin{array}{c}6.01 \pm \\
0.06^{\mathrm{a}}\end{array}$ & $\begin{array}{c}7.48 \pm \\
0.14\end{array}$ & $\begin{array}{l}6.01- \\
8.32\end{array}$ \\
\hline $\begin{array}{l}\text { Mid-early ripening } \\
(61-63)\end{array}$ & 6 & $\begin{array}{l}7.67 \pm \\
0.31^{\text {cd }}\end{array}$ & $\begin{array}{l}7.66 \pm \\
0.21^{\text {cd }}\end{array}$ & $\begin{array}{c}6.09 \pm \\
0.06^{\mathrm{a}}\end{array}$ & $\begin{array}{c}7.14 \pm \\
0.19\end{array}$ & $\begin{array}{c}6.09 \\
7.67\end{array}$ \\
\hline $\begin{array}{l}\text { Mid ripening } \\
(64-66)\end{array}$ & 61 & $\begin{array}{c}7.29 \pm \\
0.29^{b}\end{array}$ & $\begin{array}{c}7.17 \pm \\
0.13^{\mathrm{b}}\end{array}$ & $\begin{array}{c}5.87 \pm \\
0.04^{\mathrm{a}}\end{array}$ & $\begin{array}{c}6.78 \pm \\
0.15\end{array}$ & $\begin{array}{c}5.87- \\
7.29\end{array}$ \\
\hline $\begin{array}{l}\text { Mid-late ripening } \\
(67-70)\end{array}$ & 13 & $\begin{array}{c}7.98 \pm \\
0.31^{\mathrm{a}}\end{array}$ & $\begin{array}{l}8.01 \pm \\
0.23^{\mathrm{ab}}\end{array}$ & $\begin{array}{l}5.20 \pm \\
0.02^{\mathrm{c}}\end{array}$ & $\begin{array}{c}7.06 \pm \\
0.19\end{array}$ & $\begin{array}{l}5.20- \\
8.01\end{array}$ \\
\hline
\end{tabular}

Note: see Table 2. 
In 2014/2015 the average resistance was the highest as for ecogradents and other groups -8.32 , maximum -9.0 (Afina, HBF0290/ X84W063-9-392//ARH/3/LE 2301), minimum - 3.0 In 2016 the maximum resistance indicator was 8.8 (HBF0290/X84W063-9-392//ARH/ $3 /$ LE 2301), the minimum -2.5 . For three years, the average resistance of early ripening samples was 7.48 and it was the highest in comparison with other groups, with a variation range of 2.31. Over three years the varieties Afina, HBF0290/X84W063-9-39-2//ARH/3/LE 2301 were among the varieties of this group with stable resistance.

In the group of mid-early ripening samples in the 2013/2014 growing season, the average resistance was 7.67 , the maximum -8.7 , and the minimum - 6.3. In 2014/2015, the maximum resistance indicator was 9.0 (TAM302/KS93U450, MCCORMICK/TREGO), the minimum-4.6.

In 2015/2016, the average indicator was the lowest over the years of research and the highest among the groups -6.01 , the maximum 7.4 (MCCORMICK/TREGO), and the minimum - 3.0. For three years of research, the average indicator in this group was 7.14. The range of variation in the group (over years) was 1.58 points. Rina-6/4/BEZ/ NAD//KZM(ES85.24)/3/F900K, TAM302/KS93U450, MCCORMICK/ Trego showed the consistently higher resistance among the varieties of this group.

In 2014, the average resistance indicator to brown rust in the midripening group was the lowest among the studied groups and the average over the years of research -7.29 points, the maximum $-9.0(\mathrm{Ca}-$ ket/PEHLIVAN, B10/B.ARRIERO, 1/4/CHAM6//1D13.1/MLT/3/ SHI4414/CROW, TAM200/KAUZ/GOLDMARK/3/BETTY, and others), the minimum -4.1. In 2015 the average resistance indicator was 7.17 points, the highest -9.0 (Dulger-1//Vorona/BAU, Caket/Pehlivan, B10/B.Arriero, OK81306/MERCAN-2, Santa, 06393GP1, and others), minimum - 3.0. In 2015-2016, the maximum resistance indicator was 8.8 points (Caket/Pehlivan), the minimum - 2.1. This group of varieties, compared to others, had the lowest average resistance ( 5.87 points) over three years of the study. The variation rage according to the analyzed trait was 1.42 . The following samples had consistently higher resistance: T08/02, Afina, HBF0290/X84W063-9-39-2//ARH/3/LE2301, Rina-6/ 4/WITHOUT/Over//KZM(ES85.24)/3/F900K, MCCORMICK/Trego, Caket / Pehlivan, FL9547/NC00-14622, FL9547/TX00D1626.

In 2014, the average resistance indicator to brown rust in mid-late samples was 7.98 points, the maximum was - 9.0 (SD92107-2/SD99 W042, Simano, ID800994W/VEE/PIOPIO/3/MNCH/4/FDL4/Kauz, and others), and the minimum was 5.0. In 2015 the samples T08/04, SD92107-2/SD99W042, (KS95U522/TX95VA0011)F1/JAGGER, Simano showed the maximum resistance indicator ( 9 points). In 2015 2016 growing year the average indicator was the lowest over the years and groups of research -5.2 points, the maximum - 7.9 (CH111 14422), minimum - 3.2. Over three years of research, the average resistance indicator was 7.06 and the variation range was $2.81, \mathrm{~T} 08 / 02$ and Fiorina showed the highest resistance among the varieties of this group.

In the 2013-2014 growing season the average resistance indicator in early ripening samples over the years and groups of research was highest - 7.3, maximum - 8.43 (NCOO-14622/2137), minimum - 1.5 (Table 4).

\section{Table 4}

Resistance to septoria disease in samples of 4th WWSRRN CIMMYT bread winter wheat in ripeness groups, 2014-2016 $(\mathrm{x} \pm \mathrm{SD}, \mathrm{n}=4)$

\begin{tabular}{lcccccc}
\hline The group of sample & $\begin{array}{c}\text { Amounts } \\
\text { ripeness (number of } \\
\text { of samples } \\
\text { days from spring }\end{array}$ & \multicolumn{5}{c}{ Resistance to septoria disease, the score } \\
\cline { 3 - 7 } $\begin{array}{c}\text { in the } \\
\text { awakening to earing) }\end{array}$ & $\begin{array}{c}2014, \\
\text { group, pcs. }\end{array}$ & points & points & $\begin{array}{c}2016, \\
\text { points }\end{array}$ & x \pm SD & $\begin{array}{c}\text { Min- } \\
\text { Max }\end{array}$ \\
\hline Early ripening & 6 & $7.30 \pm$ & $6.27 \pm$ & $6.01 \pm$ & $6.53 \pm$ & $6.01-$ \\
(58-60) & & $0.40^{\mathrm{a}}$ & $0.17^{\mathrm{a}}$ & $0.06^{\mathrm{a}}$ & 0.39 & 7.30 \\
Mid-early ripening & \multirow{2}{*}{6} & $6.20 \pm$ & $6.13 \pm$ & $5.88 \pm$ & $6.07 \pm$ & $5.88-$ \\
(61-63) & & $0.44^{\mathrm{c}}$ & $0.03^{\mathrm{a}}$ & $0.05^{\mathrm{a}}$ & 0.10 & 6.20 \\
Mid-ripening & 61 & $6.25 \pm$ & $5.87 \pm$ & $5.73 \pm$ & $5.95 \pm$ & $5.73-$ \\
(64-66) & & $0.34^{\mathrm{b}}$ & $0.14^{\mathrm{b}}$ & $0.03^{\mathrm{b}}$ & 0.41 & 6.25 \\
Mid-late ripening & \multirow{2}{*}{13} & $4.81 \pm$ & $4.86 \pm$ & $4.72 \pm$ & $4.80 \pm$ & $4.72-$ \\
(67-70) & & $0.34^{\mathrm{b}}$ & $0.04^{\mathrm{c}}$ & $0.04^{\mathrm{c}}$ & 0.04 & 4.86 \\
\hline
\end{tabular}

Note: see Table 2.
In 2014-2015, the average resistance indicator was 6.27 and it was the average over the years and it was the highest in the groups, the maximum - 9.0 (HBF0290/X84W063-9-392//ARH/3/LE 2301), the minimum - 1.20. In 2015-2016, the average resistance indicator was the lowest over the years of research, and in the ripeness groups - the highest -6.01 points, the maximum -8.83 points (HBF0290/ X84W063-9$392 / / \mathrm{ARH} / 3 / \mathrm{LE} \mathrm{2301),} \mathrm{the} \mathrm{minimum} \mathrm{-} \mathrm{1.37.} \mathrm{In} \mathrm{the} \mathrm{early} \mathrm{ripening}$ group of varieties, compared to others, the highest average resistance indicator (6.53 points) was achieved over three years of research. The variation range was 1.29 points. The highest resistance indicator was observed over three years in the sample - HBF0290/ X84W063-9-392//ARH/3/LE2301.

In 2014 the mid-early morphotypes had the highest in years and the average for the groups -6.2 points, the maximum -8.0 (TAM302/ KS93U450, MCCORMICK/Trego), and the minimum - 4.1. In 2014 2015 resistance indicators decreased: average to 6.13 points, maximum to 7.5 (Rina-6/4/BEZ/NAD//KZM(ES85.24)/3/F900K, TAM302/KS93 U450, MCCORMICK/Trego), minimum to 3.3 .

In 2016, the average indicator was 5.88 points, the lowest by years, the maximum - 7.4 (MCCORMICK/Trego), and the minimum - 3.0. Over three years of research, the average indicator of the analyzed trait was 6.07. The variation range of the mid-ripening group was 0.32 . Among the samples of the mid-early ripening group RINA-6/4/BEZ/ NAD//KZM(ES85.24)/3/F900K， TAM302/KS93U450， RANA96/ GANSU-3, T08/02 showed the higher resistance indicator.

In the mid-ripening varieties of the 2013-2014 vegetation period, the resistance indicator was 6.25 points, the maximum - 8.4 (T07/09), the minimum -1.5 . In 2015, the maximum resistance indicator reached 9.0 points (Caket/Pehlivan), and in 2016 - 8.8 (Caket/Pehlivan). Over three years, the average resistance indicator was 5.9 points, and the variation range as for the analyzed trait was 0.52 . The samples $-107 / 09$, Caket/Pehlivan showed higher resistance indicator.

In the mid-late ripening group in 2014, the average resistance indicator to septoria disease was lowest among the groups -4.81 points, the maximum - 7.0 (T03/17, CH11114422), the minimum - 1.5. In 2015, the average resistance indicator was the highest over the years -4.86 points, the maximum -8.0 (CH11114422CH11114422), the minimum -1.2 . For $2015 / 2016$, the average trait indicator was the lowest over the years of research and in groups and it was 4.72 points, the maximum 7.9 (CH11114422), the minimum - 1.3. Over the three years of research the average resistance indicator was 4.8 points with 0.14 variation range $\mathrm{CH} 111.14422$ showed higher resistance indicator.

According to the research conducted in 2014-2016, it was determined that eleven (13\%) samples showed resistance to one disease. Three samples were resistant to powdery mildew (4\%) - TAM107/T21, Seri 1B*2/3/Kauz 2/BOW//Kauz/4/Burbot-4/5/Boema, Kukuna/TAM200//Picarel-1, six (7\%) to brown rust - Voloshkova, Dashenka, PYN/Parus/3/VPM/MOS83-11-4-8//PEW/4/Bluegil, ID800994W/ $\mathrm{VEE} / / \mathrm{PIOPIO} / 3 / \mathrm{MNCH} / 4 / \mathrm{FDL} 4 / \mathrm{Kauz}, \mathrm{OR} 2070182 \mathrm{H}$, and two (2\%) to septoria disease - Sultan, T07/09. It should be noted that this group includes the cultivars Voloshkova and Dashenka of the Ukrainian breeding, namely, cultivars from the V. M. Remeslo Mironivka Institute of Wheat.

Thirty-six samples $(43 \%)$ were resistant to two diseases: powdery mildew and brown rust $-23(27 \%)$ were mid-early ripening TAM 200/KAUZ/4/BEZ/NAD//KZM(ES8524)/3/F900K and RINA-6/4/ $\mathrm{BEZ} / \mathrm{NAD} / / \mathrm{KZM}(\mathrm{ES} 85.24) / 3 / \mathrm{F} 900 \mathrm{~K}$, mid-ripening - T08/01, PBI1013.13.3/3233.35/3/STAR//KAUZ/STAR, 1744/7C//SU/RDL/3/ Crow/4/Milan/5/Itor, X84W063-9-18/U1324-25-1-4-4//K92/3/LE2301 X84W063-9-18/U1324-25-1-4-4//K92/3/LE2301, B10/Arriero, 2//Kar192/ 3/CAMPION4/BLUEGIL-13, CMH72-428/Morocco/3/BDFN/4/ TEMU36, Lagos-11/ESKINA-3/ATAY/GALVEZ 87, TAM200/ Kauz/G/3/BETTY, Trakia/MAGA74/MON/3/SHAHI/4/EBVD99-1, RINA-6/4/BEZ/NAD//KZM(ES85.24)/3/F900K， Cv.Lada/K-62903, Cv.rodina/Ae.speltoides (10 KR) and mid-late ripening T08/04, T08/05, T03/17, SD92107-2/SD99W042, (KS95U522/TX95VA0011) F1/Jagger. Four mid-ripening samples (5\%) were resistant to powdery mildew and septoria disease - Sonmez, Star/BWD/3/PRL/VEE6//CLMS, ETA/K62905=Ester, Cv.rodinalAe.speltoides (10 KR). Nine varieties (11\%) showed resistance to brown rust and septoria disease - T07/05, T07/08, 
Dulger-1//Vorona/BAU, HBF0290/X84W063-9-392//ARH/3/LE2301, Dulger-1/Vorona/BAU1/4//1D13.1/MLT/3/SHI4414/CROW，2/MV. MAGDALENA/3/TX96V2427, KS920709-B-5-1-1/BURBOT-4, NCOO-14622/2137. Thirty-one samples (36\%) were resistant to three diseases. We identified samples that were significantly higher than the standard and were characterized by better productivity (Table 5 ).

\section{Table 5}

Characteristics of group disease resistance of the 4th WWSRRN CIMMYT winter wheat samples, average 2014-2016, $(x \pm S D, n=8)$

\begin{tabular}{|c|c|c|c|c|c|c|}
\hline \multirow[b]{2}{*}{ Sample } & \multicolumn{3}{|c|}{ Resistance to, points } & \multirow{2}{*}{$\begin{array}{l}\text { Plant } \\
\text { height, } \\
\mathrm{cm}\end{array}$} & \multirow{2}{*}{$\begin{array}{c}\text { Seed } \\
\text { weight } \\
1000, g\end{array}$} & \multirow{2}{*}{$\begin{array}{c}\text { Yield } \\
\text { capacity, } \\
\mathrm{g} / \mathrm{m}^{2}\end{array}$} \\
\hline & $\begin{array}{l}\text { Powdery } \\
\text { mildew }\end{array}$ & $\begin{array}{l}\text { Brown } \\
\text { rust }\end{array}$ & $\begin{array}{c}\text { Septoria } \\
\text { disease }\end{array}$ & & & \\
\hline Podo & $\begin{array}{c}6.10 \\
\pm 0.15^{\mathrm{a}}\end{array}$ & $\begin{array}{c}6.10 \\
\pm 0.31^{\mathrm{a}}\end{array}$ & $\begin{array}{c}5.50 \\
\pm 0.03^{\mathrm{a}}\end{array}$ & $\begin{array}{l}93.0 \\
\pm 2.2^{\mathrm{a}}\end{array}$ & $\begin{array}{l}48.00 \\
\pm 1.50^{\mathrm{a}}\end{array}$ & $\begin{array}{c}623.5 \\
\pm 48.6^{\mathrm{a}}\end{array}$ \\
\hline Fion & $\begin{array}{c}6.90 \\
\pm 0.21^{\mathrm{d}}\end{array}$ & $\begin{array}{c}7.16 \\
\pm 0.09^{\mathrm{e}}\end{array}$ & $\begin{array}{c}7.16 \\
\pm 0.25^{\mathrm{d}}\end{array}$ & $\begin{array}{l}73.9 \\
\pm 3.2^{\mathrm{f}}\end{array}$ & $\begin{array}{l}48.17 \\
\pm 1.00^{\mathrm{a}}\end{array}$ & $\begin{array}{l}539.3 \\
\pm 39.6^{\mathrm{d}}\end{array}$ \\
\hline $\mathrm{ES}$ & $\begin{array}{c}8.68 \\
\pm 0.16^{\mathrm{e}}\end{array}$ & $\begin{array}{c}8.09 \\
\pm 0.26^{\mathrm{d}}\end{array}$ & $\begin{array}{c}8.10 \\
\pm 0.15^{\mathrm{f}}\end{array}$ & $\begin{array}{l}97.5 \\
\pm 1.2^{\mathrm{d}}\end{array}$ & $\begin{array}{c}54.00 \\
\pm 1.73^{\mathrm{e}}\end{array}$ & $\begin{array}{c}857.3 \\
\pm 28.0^{\mathrm{e}}\end{array}$ \\
\hline 63 & $\begin{array}{c}7.17 \\
\pm 0.28^{\mathrm{b}}\end{array}$ & $\begin{array}{c}8.43 \\
\pm 0.07^{\mathrm{g}}\end{array}$ & $\begin{array}{c}7.23 \\
\pm 0.12^{\mathrm{h}}\end{array}$ & $\begin{array}{l}101.9 \\
\pm 1.5^{\mathrm{e}}\end{array}$ & $\begin{array}{c}51.23 \\
\pm 1.61^{\mathrm{h}}\end{array}$ & $\begin{array}{c}575.3 \\
\pm 19.2^{\mathrm{g}}\end{array}$ \\
\hline $\begin{array}{l}\text { le. } \\
\text { (KRR) }\end{array}$ & $\begin{array}{c}8.83 \\
\pm 0.12^{\mathrm{c}}\end{array}$ & $\begin{array}{c}7.64 \\
\pm 0.23^{b}\end{array}$ & $\begin{array}{c}6.88 \\
\pm 0.20^{\mathrm{b}}\end{array}$ & $\begin{array}{l}105.0 \\
\pm 2.5^{\mathrm{d}}\end{array}$ & $\begin{array}{l}53.00 \\
\pm 1.73^{\mathrm{c}}\end{array}$ & $\begin{array}{l}750.4 \\
\pm 23.2^{\text {f }}\end{array}$ \\
\hline $\begin{array}{l}\text { FL9547/NCOO- } \\
14622\end{array}$ & $\begin{array}{c}8.07 \\
\pm 0.47^{\mathrm{h}}\end{array}$ & $\begin{array}{c}8.67 \\
\pm 0.33^{\mathrm{g}}\end{array}$ & $\begin{array}{c}8.00 \\
\pm 0.17^{g}\end{array}$ & $\begin{array}{c}75.9 \\
\pm 2.2^{\mathrm{b}}\end{array}$ & $\begin{array}{c}52.43 \\
\pm 2.60^{\mathrm{g}}\end{array}$ & $\begin{array}{c}647.3 \\
\pm 12.4^{\mathrm{a}}\end{array}$ \\
\hline FL & $\begin{array}{c}7.62 \\
\pm 0.45^{\mathrm{d}}\end{array}$ & $\begin{array}{c}8.47 \\
\pm 0.29^{\mathrm{d}}\end{array}$ & $\begin{array}{c}8.00 \\
\pm 0.12^{\mathrm{f}}\end{array}$ & $\begin{array}{l}58.7 \\
\pm 1.7^{\mathrm{h}}\end{array}$ & $\begin{array}{l}52.33 \\
\pm 2.00^{f}\end{array}$ & $\begin{array}{l}579.3 \\
\pm 27.9^{d}\end{array}$ \\
\hline $\begin{array}{l}\text { MCCORMICK/ } \\
\text { Trego }\end{array}$ & $\begin{array}{c}8.28 \\
\pm 0.29^{\mathrm{f}}\end{array}$ & $\begin{array}{c}8.33 \\
\pm 0.48^{\mathrm{d}} \\
\end{array}$ & $\begin{array}{c}7.33 \\
\pm 0.19^{d} \\
\end{array}$ & $\begin{array}{r}70.7 \\
\pm 2.8^{\mathrm{g}} \\
\end{array}$ & $\begin{array}{c}52.00 \\
\pm 1.73^{\mathrm{d}} \\
\end{array}$ & $\begin{array}{c}565.5 \\
\pm 27.6^{\mathrm{g}}\end{array}$ \\
\hline
\end{tabular}

Note: see Table 2.

Among these genotypes, the highest resistance to powdery mildew was 8.83 points in sample $C v$. rodinalAe. speltoides $(10 \mathrm{KR})$, and to brown rust 8.67 points (FL9547/NCOO-14622), to septoria disease Rina-6/4/BEZ/NAD//KZM(ES8524)/3/F900K - 8.1 points.

According to complex resistance indicator, the best results were shown by two samples Rina-6/4/BEZ/NAD//KZM(ES8524)/3/F900K, FL9547/NCOO-14622 - 8.3 points. Four dwarf and three mediumgrown samples were selected among the resistant samples to the three diseases. All were characterized by a high mass of 1000 seeds. Three samples (Rina-6/4/BEZNAD//KZM(ES85.24)/3/F900K, Cv. rodina/Ae. speltoides (10 KR), FL9547/NC00-14622), which were distinguished by group resistance, exceeded the standard cultivar Podolianka by yield.

\section{Discussion}

An important role in problem solving in modern agriculture is the creation and widespread use of bread wheat that meets the requirements of production (Morhun et al., 2014). It means that the plants of these varieties must successfully withstand the adverse effects of external factors and use favourable environmental conditions with maximum efficiency. Now the new high-yielding, high-quality variety has a genetic yield capacity potential of more than 10 tha, but its production under production conditions does not exceed 30-50\% (Kolomiiets et al., 2018). It is explained by the irregularities in cultivation procedure, the lack of mineral nutrients in plants during the vegetation period, as well as the lack of adaptability of new varieties to global climate change.

The main guarantee for the creation of modern high-productive, adaptive varieties, of course, is the base line. Breeding practice confirms the need for focused search for valuable parental forms among the world's plant diversity (Bakumenko et al., 2015). The historical experience of mankind has shown that a prerequisite for the effective development of agriculture, science and education in any country is the wide utilization and testing of valuable samples of foreign plant genes (Lytvynenko \& Topal, 2015).

Prevalence of winter wheat with pathogens is a significant negative factor that reduces the quantitative and qualitative characteristics of the obtained grain harvest (Leonov et al., 2016). The main way to solve the problem of reducing the harmfulness of disease is the creation and introduction of resistant varieties. To do this the prerequisite is the selec- tion of resistance sources, the study of the genetic basis of resistance and the nature of the trait inheritance. Kovalyshyna \& Dmytrenko (2017) studied the resistance to brown rust in hybrid populations of F2 winter wheat under artificial inoculation with a pathogen in a field infestation nursery. The results of studies of 39 second-generation hybrid combinations determined that the resistance to brown rust was inherited as both a dominant and recessive trait. It was proved that the tested donors had different resistance genes to brown rust. Resistance of the donor Tx91 v 4511 is controlled with two recessive genes, Tx92 v 4511 - with one recessive gene, HBE 0303156 and HBE 0425-156 - with one dominant gene in each. Samples NVE 0140-119 and NBE 208-120 have common (identical) genes - one dominant and one recessive. All donors of this trait have resistance genes independent of the known effective ones. The availability of new donors makes it possible to enrich the bank of resistance genes to the disease and based on them to create new, non-uniform, bread winter wheat varieties.

In Uman National University of Horticulture, resistance of winter wheat varieties was studied, which revealed the phases of the highest crop damage by septoria disease (Suhomud, 2013). The damage to winter wheat with septoria leaf disease, which was dependent on the weather conditions, the phases of the crop vegetation period and the variety, was determined. The highest prevalence and extent of damage to wheat with septoria disease was found in the tube exit phase. Under conditions favourable for the pathogen development, the varieties Pyvna, Shestopalivka, Dykanka, Vasylyna and Tronka were less affected.

Khomenko \& Sandetska (2018) conducted research in the fields of the Institute of Plant Physiology and Genetics, NAS of Ukraine. As a result, the sources of complex resistance to unfavourable factors and pathogens (powdery mildew, brown rust and yellow leaf spot) were identified among the following winter wheat varieties: Natalka, Pereyaslavka, Podolyanka, Darynka, Kyivska, Zbruch, Kyivska Ostysta, Smuhlianka, Snihurka and Favorytka. The studied varieties are involved in breeding programs for the creation of a high yield capacity and highly adaptive winter wheat base line.

The susceptibility of newly developed varieties to the brown rust and powdery mildew pathogens was studied according to the results of joint research conducted by scientists of the National University of Life and Environmental Sciences of Ukraine, the Institute of Plant Protection of the NAAS and the V. M. Remeslo Mironivka Institute of Wheat (Kovalyshyn et al., 2018). During the three years of the research, the damage was within $0.1-10 \%$ and $1-20 \%$, respectively. Damage to Podolianka (the standard) with the powdery mildew pathogen over the years of research $(2015,2016,2017)$ was $10 \%, 15 \%$ and $10 \%$, respectively, and with brown rust pathogen $-10 \%, 15 \%, 0 \%$. The damage of the cultivar Keprok susceptible to the powdery mildew pathogen was at the level of $15 \%, 35 \%, 15 \%$. Brown rust developed on the susceptible cultivar Mironovskaya 10 at the level of $15 \%, 30 \%$, and in 2017 the disease on wheat plants was not shown at all. According to the results of identification of the allelic condition of the Lr34 gene, among the 15 studied varieties, only 3 varieties - Berehynya Mironovska, MIP Dniprianka and Balada Mironivska - have the Lr34 (+) allele, which is only $20 \%$ of the tested varieties. The Lr34 gene is known to be non-specific. It provides overall resistance to various brown rust pathotypes in adult plants. Therefore, the obtained results show that when creating new varieties of wheat resistant to brown rust, it is necessary to use varieties with the identified "resistant" allele of the gene Lr34, as a source of stability in breeding.

Resistance of bread spring wheat varieties to leaf fungal diseases was investigated in two ecological zones - Forest-Steppe and Polissya of Ukraine (Blyzniuk et al., 2019). The cultivar with complex resistance to pathogens - Zlata, Legyan; as for resistance to powdery mildew and brown rust - Heroinia, Panianka, Simkoda Mironivska, Yasna; as for resistance to powdery mildew and septoria - Koksa was allocated for the Forest-Steppe zone. For the Polissya zone varieties found to have complex resistance to pathogens were Zlata and Panianka, varieties with resistance to powdery mildew and brown rust were Simkoda Mironivska. It was found that the most valuable varieties were characterized by the combination of a high index of complex resistance with individual resistance to some leaf fungal diseases. In the research of Lytvynenko \& Topal (2015), a collection nursery was formed, which included breeding ma- 
terial of different genetic and environmental origin from 1T/1RS - 5 lines of the Genetic Breeding Institute (Er.3252/09, Er.3381/09, Er.532/11, Er.139/09, Er.167/11) and 27 cultivars, including Kniahynia Olha and Vykhovanka from Odessa, as well as from 1VL/1RS - 11 varieties including Schedrist odeska (SGI). DNA analysis showed that all the varieties studied in the experiment had the same 1AL/1RS translocation localized in the original Amigo variety. It was also confirmed that all varieties with $1 \mathrm{BL} / 1 \mathrm{RS}$ translocation carry the same translocation localized in the Avrora and Kavraz varieties. So the studied lines have resistance genes to powdery mildew and brown rust. The presence of wheat-rye translocations $1 \mathrm{AL} / 1 \mathrm{RS}, 1 \mathrm{BL} / 1 \mathrm{RS}$ in bread winter wheat varieties can have a negative effect on the grain quality and its baking properties of flour, due to the increased amount of water-soluble proteins - albumin and secalins (allec-1 allele) from rye (Kim et al., 2004; Litvinenko \& Topal, 2015). However, varieties with translocations $1 \mathrm{AL} / 1 \mathrm{RS}, 1 \mathrm{BL} / 1 \mathrm{RS}$ observed improvements of the flour baking properties while reducing protein gluten and increasing protein gliadin. It contributed to the better dough elasticity, ability to rise and improvement in the bread-baking properties.

The Department of Plant Genetic Improvement of the Institute of Plant Physiology and Genetics (IFRG) of the NAS of Ukraine conducts focused breeding aimed at high productivity in combination with high baking quality and a range of other economically valuable characteristics (Morgun et al., 2014)

Kozub et al. (2018) examined 20 varieties of bread winter wheat from competitive testing for reserve protein loci. Particular attention was paid to new varieties Syntetyk and Bohdanka with rye material, which were also studied using cytogenetic analysis. Among the studied group of varieties, rye material at gliadic encoding loci was found in three cultivars - Syntetyk, Kryzhynka and Bohdanka. Syntetyk and Kryzhynka were found to have rye translocation of 1BL/1RS, and Bohdanka cultivar $-1 \mathrm{AL} / 1 \mathrm{RS}$. These facts were confirmed cytologically. The allelic condition form mode of the Gliadin Gli-1 (Gld) and HMW loci of the glutenin Glu-1 subunits in the studied set of varieties was determined. Genealogy of the first bread wheat variety of winter breeding in the Russian Federation with translocation 1AL/1RS - Bohdanka is specified.

Over the years, scientists from Ukraine, countries from the CIS and non-CIS have conducted a number of studies in this field and obtained significant results as for the identification of resistance genes to brown rust, powdery mildew, septoria, pyrenophorosis (Leonov et al., 2016). In practical terms, winter wheat lines were created using distant and intraspecific hybridization, which had value as a base line for creating resistant varieties. Since the loss of resistance varieties is a natural process due to changes in the populations of pathogens, the variability of environmental conditions, so the search for new sources of disease resistance, expanding the genetic diversity of existing winter wheat varieties, the study of the composition of pathogens and identification of new resistance genes could be a permanent and constant selection process for any crop, and in particular wheat.

Based on our research during 2014-2016 on resistance to leaf diseases of the 4th WWSRRN CIMMYT samples, $36 \%$ out of all studied samples resistant to three diseases were identified. Genotypes which exceeded the standard as for resistance and were characterized by better performance were identified. Among them were valuable forms for breeding work which can be donors of resistance to leaf diseases; Fiorina, Rana 96/GANSU-3, Zander-17/3/YE2453/KA//1D13.1/MLT, Rina-6/4/WITHOUT/HOPE/KZM(ES85.24)/3/F900K, 06393GP1, Cv.rodinalAespeltoides (10 KR), FL9547/NC00-14622, FL9547/TX00 D1626, MCCORMICK/Trego. In terms of complex resistance, the best results were shown by two samples Rina-6/4/BEZ/NAD//KZM (ES8524)/3/F900K and FL9547/NCOO-14622 - 8.3. The next step in our work is to create a new base line using the best CIMMYT samples, with a combination of individual and group resistance to major diseases and a complex of valuable economic traits.

\section{Conclusion}

According to the results of two-factor dispersion analysis it was determined that the manifestation of variability of the analyzed trait in the 4th WWSRRN samples relative to the investigated diseases reliably depended mainly on the genotype of the variety and much less on the ecogradient and the interaction of these sources. The highest percentage of genotype effect was observed for septoria disease resistance - $81 \%$. According to the vegetation period samples were divided into four groups: early ripening -6 , mid-early ripening -6 , mid-ripening -61 , mid-late ripening -13 . As for resistance to powdery mildew for the three years of research, the mid-late ripening samples showed the highest indicator -7.7 . In this group, the maximum value was 8.9 points and the minimum value was 2.3 . The smallest variation range of resistance (1.3 points) was identified in the mid-early ripening group. It means that they most adapted to powdery mildew in the NorthEastern Forest-Steppe.

After three years of research, the highest average resistance indicator to brown rust was 7.5 points and it was found in the early ripening group. The maximum resistance value was 8.7 points and the minimum value was 4.3 . The samples of the mid-ripening group were the most adaptable to the brown rust pathogen.

The highest average resistance to septoria disease was also recorded in the early ripening group. The maximum indicator was found at 8.3 points and the minimum one was 1.3. The highest adaptability to septoria disease was observed in the samples of mid-late ripening group.

According to the research conducted in 2014-2016 thirty-one samples $(36 \%)$ were resistant to three diseases. The highest resistance to powdery mildew was in the Cv.rodinalAespeltoides $(10 \mathrm{KR})-8.9$, to brown rust in FL9547/NCOO-14622 - 8.7, to septoria disease Rina6/4/BEZ/NAD//KZM(ES8524)/3/F900K) - 8.1. According to the complex resistance indicator, the best results were shown by two samples: Rina-6/4/BEZ/NAD//KZM(ES8524)/3/F900K and FL9547/NCOO$14622-8.3$. Genotypes that exceeded the standard for resistance were identified and they were characterized by better performance indicators. Among them the following valuable forms for breeding work which can be donors of resistance to leaf diseases are identified: Fiorina, Rana 96/GANSU-3， Zander-17/3/YE2453/KA//1D13.1/MLT， Rina-6/4/ WITHOUT/HOPE//KZM(ES85.24)/3/F900K, 06393GP1, Cv.rodinalAe.speltoides (10 KR), FL9547/NC00-14622, FL9547/ TX00D1626, MCCORMICK/Trego. It is possible to create new breeding material with them.

\section{References}

Adamski, T., Krystkowiak, K., Kuczynska, A., Mikolajczak, K., Ogrodowicz, P., Ponitka, A., Surma, M., \& Slusarkiewicz-Jarzi, A. (2014). Segregation distortion in homozygous lines obtained via anther culture and maize doubled haploid methods in comparison to single see descent in wheat (Triticum aestivum L.). Electronic Joumal of Biotechnology, 8, 1-8.

Ardalani, S., Mirzaghaderi, G., \& Badakhshan, H. (2016). A Robertsonian translocation from Thinopyrum bessarabicum into bread wheat confers high iron and zinc contents. Plant Breeding, 135, 286-290.

Bakumenko, O. M., \& Vlasenko, V. A. (2018). Efekty pshenychno-zhytnix translokacij na kombinacijnu zdatnist sortiv pshenyci ozymoyi [Effects of wheatrye translocations on the combining ability of winter bread wheat cultivars]. Breeding and Seed Production, 113, 8-17.

Bakumenko, O. M., Osmachko, O. M., \& Vlasenko, V. A. (2015). Vplyv pshenychno-zhytnih translokacij 1AL/1RS i 1BL/1RS na elementy produktyvnosti v F1 pshenyci myakoyi ozymoyi [The effect of wheat-rye translocations 1AL/1RS and 1BL/1RS on performance elements in F1 bread winter wheat]. ScienceRise, 12(17), 69-75.

Blyznyuk, R. M., Demydov, O. A., Chugunkov, T. V., Fedorenko, M. V., \& Berezovskyj, D. Y. (2019). Stijkist sortiv pshenyci myakoyi yaroyi do lystkovyh grybnyh hvorob [Resistance of bread spring wheat varieties to leaf fungal diseases]. Agroecologigal Jornal, 1, 74-79.

Brygadyrenko, V. V., \& Nazimov, S. S. (2015). Trophic relations of Opatrum sabulosum (Coleoptera, Tenebrionidae) with leaves of cultivated and uncultivated species of herbaceous plants under laboratory conditions. Zookeys, 481, 57-68.

Calvo-Salazar, V., Singh, R. P., Huerta-Espino, J., Cruz-Izquierdo, S., Lobato-Ortiz, R, Sandoval-Islas, S., Vargas-Hernández, M., German, S., Silva, P., Basnet, B. R., Lan, C. X., \& Herrera-Foessel, S. A. (2015). Genetic analysis of resistance to leaf rust and yellow rust in spring wheat cultivar Kenya Kongoni. Plant Disease, 99(8), 1153-1160.

Chhetri, M., Toor, A., \& Bariana, H. (2016). Development of robust molecular markers for marker-assisted selection of leaf rust resistance gene Lr23 in common and durum wheat breeding programs. Euphytica, 209, 637-649. 
Dospehov, B. A. (1985). Metodika polevogo opyta [Field experiment methodology]. Agropromizdat, Moscow (in Russian).

Fahmi, A. I., El-Shehawi, A. M., \& El-Orabey, W. M. (2015). Leaf rust resistance and molecular identification of $\mathrm{Lr} 34$ gene in egyptian wheat. Journal of Microbial and Biochemical Technology, 7(6), 338-343.

Hao, M., Liu, M., Luo, J., Fan, C., Yi, Y., Zhang, L., Yuan, Z., Ning, S., Zheng, Y, \& Liu, D. (2018). Introgression of powdery mildew resistance gene Pm56 on rye chromosome Arm 6RS into wheat. Frontirs in Plant Science, 17, 1-8.

Khomenko, L. O., \& Sandeczka, N. V. (2018). Dzherela kompleksnoyi stijkosti pshenyci ozymoyi (Triticum aestivum L.) u selekciyi na adaptyvnist' [Sources of complex resistance of winter wheat (Triticum aestivum L.) for adaptive breeding]. Breeding and Seed Production, 14(3), 270-276.

Khondoker, A. M., Pawan, K. S., Sonder, K., Kruseman, G., \& Erenstein, O. (2019). Averting wheat blast by implementing awheat holiday: In: Search of alternative crops in West Bengal, India. PLoS One, 14(2), e0211410.

Kim, W., Johnson, J. W., Baenziger, P. S., Lukaszewski, A. J., \& Gaines, C. S. (2004). Agronomic effect of wheat-rye translocation carrying rye chromatin (1R) from different sources. Crop Science, 44(4), 1254-1258

Koller, T., Brunner, S., Herren, G., Humi, S., \& Keller, B. (2018). Pyramiding of transgenic Pm3 alleles in wheat results in improved powdery mildew resistance in the field. Theoretical and Applied Genetics, 131, 861-871.

Kolomiiets, L. A., Humeniuk, O. V., Derhachov, O. L., \& Koliadenko, S. S. (2018). Novyj sort pshenytsi miakoji ozymoi "Horlytsia Myronivska" [A new variety of soft winter wheat "Horlytsia Myronivska"]. Plant Varieties Studying and Protection, 4(1), 21-27.

Kovalyshyna, G. M., \& Dmytrenko, Y. M. (2017). Dzherela stijkosti proty zbudnyka buroji irzhi ta yikh vykorystannia u protsesi stvorennia sortiv pshenytsi mjakoji [Sources of resistance to brown rust pathogen and their use in the development of bread wheat varieties]. Plant Varieties Studying and Protection, 13(2), 379-386.

Kovalyshyna, G. M., Dmytrenko, Y. M., Demydov, O. A., Mukha, T. I., \& Murashko, L. A. (2017). Selektsija pshenytsi ozymoji na stijkist' proty khvorob [Winter wheat breeding for disease resistence]. Breeding and Seed Production, 269, 99-110.

Kovalyshyna, G. M., Dmytrenko,Y. M., Karelov, A. V., Sozinov, I. O., Kozub, N. O., \& Gumenyuk, O. V. (2018). Kharakterystyka novyh sortiv pshenyci myakoyi ozymoyi myronivskoji selekciji za alel'nym stanom gena stijkosti proty zbudnyka buroyi irzhi Lr34 [Characteristics of new varieties of winter common wheat breeding of the myronivka institute of wheat as the allelic state of the Lr34 leaf rust resistance gene]. Life and Environmental Sciences, 10(3-4), 139-146.

Kyrychenko, V. V., Petrenkova, V. P., Chernyayeva, I. M., Markova T. Y., Popov, V. M., Luchnaya, I. S., Babushkina, T. V., Ryabchun, N. I., Zvyagin, A. F., Leonov, O. Y., Vasko, N. I., Kozachenko, M. R., Zvyaginceva, A. M., Yegorov, D. K., Derevyanko, V. P., Ryabchun, V. K., Kapustina, T. B., Melnyk, B. S., Chernobaj, L. M., Kozubenko, L. V., Kytajova, S. S., Ponurenko, S. G., Grygorashhenko, L. V., Gorbachova, S. M., Sokol, T. V., Bezuglyj, I. M., Vasylenko, A. O., Ryabuxa, C. S., Borovska, I. Y., Maklyak, K. M., \& Kolomaczka, V. P. (2012). Osnovy selekciji poliovyh kul'tur na stijkist do shkidlyvyh organizmiv [Fundamentals of field crop breeding to pathogen resistance]. Y. Yuriev Plant Production Institute, Kharkiv (in Ukrainian).

Leonov, O. Y., Petrenkova, V. P., Luchna, I. S., Suvorova, K. Y., \& Chuguyev, S. V. (2016). Hvoroby pshenyci, poshyreni v Ukrajini: shkidlyvist', genetychnyj kontrol' ta rezul'tatyvnist' selekciji na stijkist' [Wheat diseases common in Ukraine: Harmfulness, genetic control and effectiveness of breeding for resistance]. Breeding and Seed Production, 109, 53-92.

Li, M., Tang, Z., Qiu, L., Wang, Y., Tang, S., \& Fu, S. (2016). Identification and physical mapping of new PCR-based markers specific for the long arm of rye (Secale cereale L.) chromosome 6. Journal of Genetics and Genomics, 43(4), 209-216.

Liu, N., Bai, G., Lin, M., Xu, X., \& Zheng, W. (2017). Genome-wide association analysis of powdery mildew resistance in U.S. winter wheat. Scientific Reports, 7(11743), 1-11.

Liu, N., Liu, Z. L., Gong, G., Zhang, M., Wang, X., \& Zhou, Y. (2015). Virulence structure of Blumeria graminis f. sp. tritici and its genetic diversity by ISSR and SRAP profiling analyses. PLoS One, 10(6), 1-20.

Liu, W., Koo, D. H., Xia, Q., Li, C., Bai, F., \& Song, Y. (2017). Homoeologous recombination-based transfer and molecular cytogenetic mapping of powdery mildew-resistant gene Pm57 from Aegilops searsii into wheat. Theoretical and Applied Genetics, 130, 841-848.
Liu, W., Koo, D., Friebe, B., \& Gill, B. S. (2016). A set of Triticum aestivumAegilops speltoides Robertsonian translocation lines. Theoretical and Applied Genetics, 129(12), 2359-2368

Lytvynenko, M. A., \& Topal, M. M. (2015). Pshenychno-zhytni translokacij 1AL/1RS i 1VL/1RS ta yakist zerna u sortiv pshenyci myakoyi ozymoyi [Wheat-rye translocations $1 \mathrm{AL} / 1 \mathrm{RS}$ and 1BL/1RS for grain quality in soft winter wheat varieties]. Scientific Journal, 311(8), 82-87.

Mamoudou, S., Changyou, W., Alam, M. A., Chunhuan, C., \& Wanquan, J. I. (2016). Genetic analysis of powdery mildew resistance gene using SSR markers in common wheat originated from wild emmer (Triticum dicoccoides Thell). Field Crops, 21(1), 10-15.

McIntosh, R. A., Yamazaki, Y., Dubcovski, J., Rogers, W. J., Morris, C. F., Sommers, D. J., Appels, R., \& Devos, K. M. (2008). Catalogue of gene symbols for wheat. 11th International wheat genetics symposium. Brisbane Qld.

Morgun, V. V., Gavrylyuk, M. M., Oksom, V. P., Morgun, B. V., \& Pochynok, V. M. (2014). Vprovadzhennya u vyrobnycztvo novyh, stijkyh do stresovyh faktoriv, vysokoproduktyvnyh sortiv ozymoyi pshenyci, stvorenyh na osnovi vykorystannya hromosomnoyi inzheneriyi ta marker-dopomizhnoyi selekciyi [Introduction of new, stress resistant, high-yielding winter wheat varieties based on chromosome engineering and marker-assisted selection]. Science and Innovation, 10(5), 40-48 (in Ukrainian).

Mukha, T. I., \& Zayima, O. A. (2013). Harakterystyka novyh sortiv pshenyci ozymoyi myronivs'koyi selekciyi za stijkistiu proty septoriozu lystya [Characterization of new wheat varieties of winter myroniv breeding as for resistance to leaf septoria disease]. Breeding and Seed Production, 103, 271-276.

Olson, E. L., Brown-Guedira, G., Marshalf, D. S., Jin, Y., Mergoum, M., Lowe, I. \& Dubcovsky, J. (2010). Genotyping of U.S. wheat germplasm fro presense of stem rust resistance genes Sr24, Sr36, and Sr1RSAmigo. Crop Scuence, $50,668-675$.

Pretorius, Z. A. (2000). Detection of virulence to wheat stem rust resistance gene $\mathrm{Sr} 31$ in Puccinia graminis f. sp. tritici in Uganda. Plant Disease, 84(2), 203.

Qiu, L., Tang, Z. X., Li, M., \& Fu, S. L. (2016). Development of new PCR-based markers specific for chromosome arms of rye (Secale cereale L.). Genome, 59, 159-165.

Reshetniak, D. Y., Pakhomov, O. Y., \& Brygadyrenko, V. V. (2017). Possibility of identifying plant components of the diet of Harpalus rufipes (Coleoptera, Carabidae) by visual evaluation. Regulatory Mechanisms in Biosystems, 8(3), 377-383.

Shyshkyn, N. V., Derov, T. G., Gultyaeva, E. Y., \& Shajdayuk, E. L. (2018). Identification of the genes resistant to brown rust in winter soft wheat varieties with the use of conventional and modern research methods. Plant Protection, $59,63-67$

Suxomud, O. G. (2013). Resistance of winter wheat to the lesion by septoria spot depending on the variety. The Latest Agrotechnology, 1(1), 11-17.

Vlasenko, V. A., Kochmarskyi, V. S., Koliuchyi, V. T., Kolomiiets, L. A., Khomenko, S. O., \& Solona, V. Y. (2012). Selektsijna evoliutsija myronivskyh pshenyts [Breeding evolution of Myroniv wheat]. Myronivka (in Ukrainian).

Volkodav, V. V. (2003). Metodyka derzhavnoho vyprobuvannia sortiv roslyn na prydatnist do poshyrennia $v$ Ukrajini [State testing methodology of plant varieties for spread adaptation in Ukraine]. In: Right protection of plant variety: Official bulletin. Alefa, Kyiv (in Ukrainian).

Vozhzhova, N. N. (2018). Identyfikaciya gena ustojchyvosti k buroj rzhavchyne Lr34 v sortax y kollekcionnyh obrazcah ozymoj myagkoj pshenyczy Agrarnogo nauchnogo centra "Donskoj" [Identification of the Lr34 gene for resistance to leaf rust in varieties and collection samples of winter soft wheat from the Agricultural Research Center "Donskoy"]. Vavilov Journal of Genetics and Breeding, 22(3), 329-332.

Wiersma, A. T., Pulman, J. A., Brown, L. K., Cowger, C., \& Olson, E. L. (2017) Identification of Pm58 from Aegilops tauschii. Theoritical Applied Genetics, 130(6), 1123-1133.

Yachevska, G. L. (1990). Ispol'zovanije metoda otdalennoj gibridizacii v selekcii pshenicy [Using the remote hybridization method in wheat breeding]. Agroprominform, Moscow (in Russian)

Zeng, D., Luo, J., Li, Z., Chen, G., Zhang, L., \& Ning, S. (2016). High transferability of homoeolog-specific markers between bread wheat and newly synthesized hexaploid wheat lines. PLoS One, 11(9), 1-10.

Zhang, R., Sun, B., Chen, J., Cao, A., Xing, L., \& Feng, Y. (2016). Pm55, a developmental-stage and tissue-specific powdery mildew resistance gene introgressed from Dasypyrum villosum into common wheat. Theorical Applied Genetics, 129, 1975-1984. 